\title{
IDENTIFIKASI POTENSI KEJADIAN PETIR DI SULAWESI UTARA
}

\author{
Seni Herlina J. Tongkukut ${ }^{1)}$ \\ ${ }^{1)}$ Program Studi Fisika FMIPA Universitas Sam Ratulangi, Manado 95119
}

\begin{abstract}
ABSTRAK
Telah dilakukan identifikasi potensi kejadian petir di Sulawesi Utara dengan menggunakan data hasil pendeteksian kejadian hari petir sejak tahun 2000 sampai 2008. Pendeteksian kejadian hari petir dilakukan oleh BMKG Sulawesi Utara di stasiun Manado, Bitung, Tondano, Naha dan stasiun Gorontalo. Data yang telah diolah disajikan dalam bentuk peta Iso Keraunik Level (IKL) yang menggambarkan tingkat potensi petir masing-masing daerah pengamatan. Diperoleh hasil bahwa Sulut banyak mengalami kejadian hari petir sepanjang tahun 2000-2008 khususnya Bolaang Mongondow Utara, Tondano dan Manado. Tingkat potensi petir tertinggi meliputi Bolaang Mongondow Utara dan Gorontalo sebesar 48\% disusul Tondano 42\% lalu Manado sebesar 38\%, Bitung 17\% dan terakhir Naha $11 \%$.
\end{abstract}

Kata kunci: iso keraunik level, petir

\section{IDENTIFICATION OF THE POTENTIAL FOR LIGHTNING OCCURRENCE IN NORTH SULAWESI}

\begin{abstract}
Identification of the potential for lightning occurrence in North Sulawesi using the data detection result from 2000 until 2008. The detection of lightning events were conducted by BMKG stations of Manado, Bitung, Tondano, Naha and Gorontalo. The processed data were presented in the map of the isocronic level that described the lightning potential level in each observation location. The results indicated that North Sulawesi experienced many lightning events during 2000-2008, especially in North Bolaang Mongondow, Tondano and Manado. The highest potential level of lightning was North Bolaang Mongondow as well as Gorontalo (48\%), followed by Tondano (42\%), Manado (38\%), Bitung (17\%), and the lowest was Naha (11\%).
\end{abstract}

Keywords : isocronic level, lightning

\section{PENDAHULUAN}

Kepulauan Indonesia yang terletak pada $7^{\circ} \mathrm{LU}-12^{\circ} \mathrm{LS}$ dan $94^{\circ} \mathrm{BT}-142^{\circ} \mathrm{BT}$ merupakan daerah khatulistiwa atau daerah tropis dengan tingkat pemanasan dan kelembaban tinggi. Kondisi ini mengakibatkan potensi kejadian petir menjadi sangat tinggi dibanding dengan daerah sub tropis (Tjasyono, 2005). Menurut Uman (2001), petir merupakan suatu fenomena kelistrikan udara di alam yang bermula dari proses terbentuknya muatan listrik positip dan negatip di dalam awan. Jika medan listrik di udara membesar artinya potensial bertambah dan jika beda potensial antara keduanya cukup besar, maka akan terjadi pelepasan muatan (lightning discharge) untuk mencapai kesetimbangan dan terjadilah petir.
Besarnya energi yang dihasilkan oleh satu sambaran petir mencapai 55 kwhours. Jika sambaran ini mengenai manusia maka pasti menyebabkan kematian dan jika mengenai benda seperti gedung maka akan menyebabkan kerusakan besar. Menurut Zorro (2009), sambaran petir dapat berupa sambaran langsung seperti yang menyebabkan kerusakan pada gedung atau sambaran tidak langsung berupa radiasi, konduksi atau induksi gelombang elektromagnetik (lightning electromagnetic pulse). Sambaran tidak langsung tidak kalah merusaknya karena gelombang elektromagnet yang menyebar dapat merusak peralatan elektronika seperti pada peralatan rumah tangga, peralatan industri, perbankan dan instalasi penting lainnya yang bahkan dapat mencapai jarak $2 \mathrm{~km}$ dari sumber petir (Sulistyanto, 2002). Dengan demikian petir 
merupakan fenomena alam yang harus diusahakan untuk meminimalkan kerugian yang ditimbulkannya.

Salah satu usaha awal untuk meminimalkan kerugian akibat petir adalah mengidentifikasi potensi kejadian petir di suatu daerah. Setiap daerah mempunyai potensi yang berbeda karena selain berhubungan dengan keadaan udara, potensi petir juga berhubungan dengan topografi daerah tersebut (Tjasyono, 2001). Potensi terjadinya petir atau tingkat kerawanan petir di suatu daerah dapat diidentifikasi dengan membuat peta hari guruh IKL (isocronic level) daerah tersebut. Data yang dipetakan pada peta IKL berasal dari data pengamatan kejadian petir setiap hari yang direkam oleh alat perekam petir (lightening detector) yang di miliki oleh Badan Meteorologi Klimatologi dan Geofisika. Sehubungan dengan hal ini, penting untuk mengidentifikasi potensi petir Sulut dan sekitarnya dengan membuat peta Iso Keraunik Level daerah Sulut.

\section{TINJAUAN PUSTAKA}

Petir adalah fenomena kelistrikan udara berupa pelepasan muatan listrik yang terjadi di udara karena adanya perbedaan medan listrik antara dua massa dengan muatan listrik yang berbeda untuk mencapai kesetimbangan (Griffith, 1995). Pelepasan muatan atau petir dapat terjadi di dalam awan, antara awan dengan awan dan antara awan dan permukaan bumi (Wahid, 2009).

Jenis awan yang dapat menimbulkan petir adalah awan cumulonimbus $(\mathrm{Cb})$ yang cenderung menggumpal dan menjulang tinggi. Awan cumulonimbus berasal dari awan stratus yang berkembang menjadi awan cumulus. Dalam fase cumulus terdapat gerak vertikal uap air ke atas. Setelah fase cumulus, awan cumulonimbus memasuki fase matang. Pada fase ini fisik awan menjadi tinggi menjulang dan ditandai hujan lebat 10 sampai 15 menit. Pada fase ini juga awan dapat mencapai ketinggian $13 \mathrm{~km}$ dan awanpun masih bergerak ke atas dengan kecepatan naik 1-1,5 km/menit. Dalam fase inilah dapat terjadi petir (Tjasyono, 2001). Menurut Lee (2010) petir hanya terjadi pada awan yang bergerak ke atas dan melebihi tingkat pembekuan karena pemisahan muatan berkaitan dengan kristal-kristal es. Kristal yang lebih ringan bertumbukan dengan butiran-bitiran es yang lebih berat di dalam awan. Kristal yang lebih ringan membentuk muatan positip dan bergerak ke bagian atas awan sedangkan butiran-butiran es yang berat bermuatan negatip dan bergerak ke bagian bawah awan seperti pada Gambar 1 .

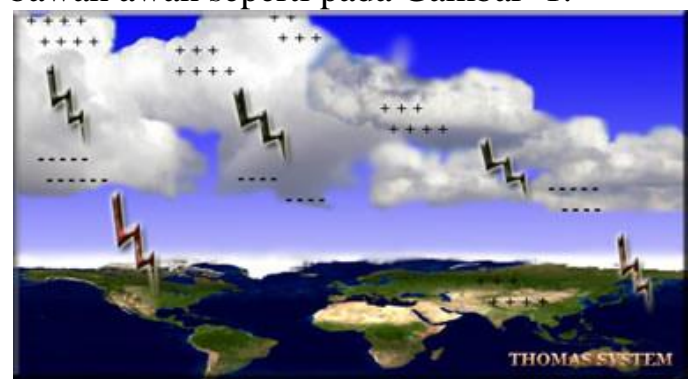

Gambar 1. Pemisahan muatan positip dan negatip dalam awan cumulonimbus

Muatan negatip pada awan bagian bawah menyebabkan daerah di permukaan tanah di bawah awan tersebut menjadi bermuatan positip. Objek yang menonjol dari permukaan tanah bermuatan positip lebih rapat seperti pohon, gedung dan tiang-tiang (Pinto, 2007). Dari sisi ini, petir merupakan gejala alam yang dapat dianalogikan sebagai kapasitor raksasa dengan awan sebagai salah satu lempeng dan bumi sebagai lempeng lainnya. Petir sebagai peristiwa pelepasan muatan terjadi karena adanya perbedaan potensial listrik antara awan dan bumi (Griffith, 1995).

Sambaran petir dapat memanaskan udara yang dilaluinya hingga $30.000^{\circ} \mathrm{C}(5$ kali lebih panas dari permukaan matahari). Pemanasan yang ekstrim ini menyebabkan udara mengembang sangat cepat dan membentuk gelombang kejut yang menjadi bom gelombang suara (guntur) dan menjalar ke sekitarnya. Dibutuhkan 3 detik bagi guntur untuk menjalar sejauh $1 \mathrm{~km}$.

Petir yang terjadi di dalam awan, antar awan atau antara awan dan bumi, semuanya berpotensi membawa akibat yang tidak diinginkan. Jika petir antara awan dan bumi beresiko mengancam keselamatan makhluk hidup dan benda-benda di bumi maka petir dalam awan atau antara awan berpotensi mengancam keselamatan penerbangan.

Sambaran petir dibagi atas sambaran langsung dan sambaran tidak langsung. Sambaran langsung adalah sambaran yang langsung ke benda atau obyek sambaran, 
sedang sambaran tidak langsung adalah sambaran melalui radiasi, konduksi atau induksi gelombang elektromagnetik petir (Zorro, 2009). Kedua jenis sambaran ini dapat menimbulkan kerusakan pada peralatan-peralatan elektronik di luar atau di dalam ruangan. Sambaran tidak langsung merupakan sambaran petir di kawasan dekat suatu jaringan elektronika yang memberikan efek pada jaringan tersebut. Efek sambaran tidak langsung berasal dari munculnya gelombang elektromagnetik yang dirambatkan ke sekitar petir. Medan listrik dihasilkan dari adanya muatan-muatan listrik lokal di dalam atmosfer sedangkan medan magnet ditimbulkan oleh adanya muatan listrik yang bergerak menuju bumi (Sulistyanto, 2002).

Potensi petir suatu daerah berhubungan dengan keadaan udara di daerah tersebut yang dibutuhkan untuk terjadinya petir yaitu: terdapat pemanasan yang cukup sehingga penguapan menghasilkan uap air yang banyak di udara, terdapat pergerakan angin yang akan mengumpulkan awan, mempunyai kelembaban udara yang tinggi atau terdapat kandungan uap air yang tinggi di udara serta adanya dorongan ke atas oleh rintangan yang tinggi seperti gunung untuk membantu terbentuknya awan cumulonimbus (wahid, 2009).

\section{METODE PENELITIAN}

Penelitian ini dilaksanakan di Lab. Geofisika Jurusan Fisika FMIPA Unsrat dan Badan Meteorologi, Klimatologi dan Geofisika Manado yang bekerjasama dengan stasiun pengamatan Gorontalo, Tondano, Bitung dan Naha. Alat yang digunakan adalah seperangkat Lightning Detector, Program Geographical Information System (GIS) serta alat tulis. Metode penelitian meliputi studi literature dan pengumpulan data petir dari BMKG Sulut yang kemudian diolah dan dipetakan dengan program GIS untuk mendapatkan peta IKL yang selanjutnya diinterpretasi.

\section{HASIL DAN PEMBAHASAN}

\section{Iklim Indonesia}

Indonesia dengan posisinya di equator mengalami iklim tropis yaitu pada bulan April -September ketika matahari di utara, Indonesia mengalami musim kemarau.
Sebaliknya pada bulan Oktober - Maret, matahari berada di selatan dan Indonesia mengalami musim hujan. Tingkat pemanasan yang relatif tinggi sepanjang tahun mengakibatkan tingkat penguapan tinggi dan akibatnya secara umum Indonesia mempunyai tingkat kelembaban udara yang juga tinggi. Faktor ini sangat menunjang syarat yang dibutuhkan untuk terbentuknya awan petir.

\section{Iklim Sulaweai Utara}

Sulawesi Utara berada pada posisi $121^{\circ}$ BT- $127^{\circ} \mathrm{BT}$ serta $1^{\circ} \mathrm{LU}-4^{\circ} \mathrm{LU}$ dan termasuk kawasan beriklim tropis dengan tingkat pemanasan tinggi sepanjang tahun. Sulawesi Utara mengalami dua musim yaitu musim hujan dan musim kemarau dan menurut data BMKG Manado, pola hujan Sulut adalah musim hujan yang lebih panjang dengan musim panas yang relatif singkat (Munawar, 2010).

Pengamatan petir di Sulawesi Utara dan sekitarnya dilakukan di lima stasiun yaitu Bitung, Manado, Tondano, Naha dan Gorontalo. Karakteristik kelima daerah tersebut adalah (Salmawati, 2010):

\section{a. Bitung}

Secara topografis, sebagian besar daratan Bitung berada pada ketinggian $0-200 \mathrm{mdpl}$. Pola curah hujan bulanan dari tahun 19992008 menurut data dari BMKG Kayuwatu Manado adalah November hingga Juni mengalami musim hujan dengan intensitas di atas $150 \mathrm{~mm} / \mathrm{bulan}$ serta bulan juli sampai oktober mengalami musim panas.

\section{b. Manado}

Manado adalah kawasan yang sebagian besar berada pada ketinggian $0-200 \mathrm{mdpl}$. Pola curah hujan bulanan dari tahun 19992008 menurut data dari BMKG Kayuwatu Manado adalah pada bulan Oktober hingga Juni mengalami musim hujan dengan puncak musim hujan pada bulan Januari dengan intensitas $518 \mathrm{~mm} / \mathrm{bulan}$. Pada bulan Juli hingga September Manado mengalami musim panas dengan puncaknya pada bulan Agustus.

\section{c. Tondano}

Wilayah Tondano berada pada ketinggian 0-500 mdpl. Di utara dan selatannya terdapat kawasan dengan ketinggian yang mencapai 1500 mdpl. Pola curah hujan bulanan dari tahun 1999-2008 menurut data dari BMKG 
Kayuwatu Manado adalah pada bulan Oktober hingga Juni mengalami musim hujan dengan puncak musim hujan pada bulan November dengan intensitas $307 \mathrm{~mm} / \mathrm{bulan}$. Pada bulan Juli hingga September Tondano mengalami musim panas dengan puncaknya pada bulan Agustus.

\section{d. Naha}

Naha berada di kep. Sangihe yaitu kabupaten dengan beberapa pulau kecil. Pola curah hujan bulanan di Naha dari tahun 19992008 menurut data dari BMKG Kayuwatu Manado adalah Naha nyaris mengalami musim hujan sepanjang tahun dengan intensitas paling tinggi pada bulan Januari yang mencapai $540 \mathrm{~mm} /$ bulan. Musim panas hanya terjadi pada bulan Agustus.

\section{e. Gorontalo}

Gorontalo adalah propinsi yang berbatasan dengan Sulawesi Utara di bagian timurnya. Topografi daratannya cenderung bergunung-gunung selain juga terdapat danau.

\section{Kejadian Petir di Sulawesi Utara dan Sekitarnya}

Badan Meteorologi, Klimatologi dan Geofisika stasiun geofisika klas I Winangun Manado yang bekerja sama dengan stasiun geofisika Bitung, Tondano, Gorontalo dan Naha telah mendeteksi dan mencatat kejadian petir di Sulawesi Utara dan sekitarnya dengan menggunakan detektor petir (Lightning Detector/2000).
Dalam penelitian ini diambil data kejadian petir dari tahun 2000-2008 dengan data berupa data hari petir yaitu hari dengan ada kejadian petir. Kelima stasiun pengamatan mengamati kejadian petir pada daerahnya masing-masing dengan jangkauan deteksi pada radius $50 \mathrm{~km}$ dan melingkupi pusat deteksi.

Data hari petir dihitung jumlahnya untuk tiap bulan selama tahun 2000 sampai tahun 2008 pada kelima stasiun pengamatan. Selanjutnya untuk bulan yang sama jumlah hari petir dijumlahkan lagi untuk kurun waktu tahun 2000 sampai 2008 (selama 9 tahun). Terakhir data hari petir disajikan dalam bentuk prosentase hari petir setiap bulannya selama 9 tahun yaitu perbandingan hari dengan ada kejadian petir pada bulan tertentu selama 9 tahun terhadap keseluruhan hari pada bulan yang sama selama 9 tahun. Persamaan prosentase tersebut dinyatakan seperti berikut (Wahid, 2009):

$a$
$=\frac{\text { jumlah hari petir dalam satu bulan selama } 9 \text { tahun }}{\text { jumlah hari dalam satu bulan yang sama selama } 9 \text { tahun }} \times 100 \%$
dengan a adalah prosentase hari petir.

Gambar 2. memperlihatkan bahwa daerah dengan potensi petir terbesar berada pada daerah Gorontalo disusul Tondano, Manado, Bitung dan yang terendah adalah di Naha. Potensi yang terdeteksi detektor di Gorontalo juga berlaku di daerah Bolaang Mongondow Utara Propinsi Sulawesi Utara dengan kata lain untuk Sulawesi Utara potensi petir terbesar terdapat di kabupaten Bolaang Mongondow Utara.

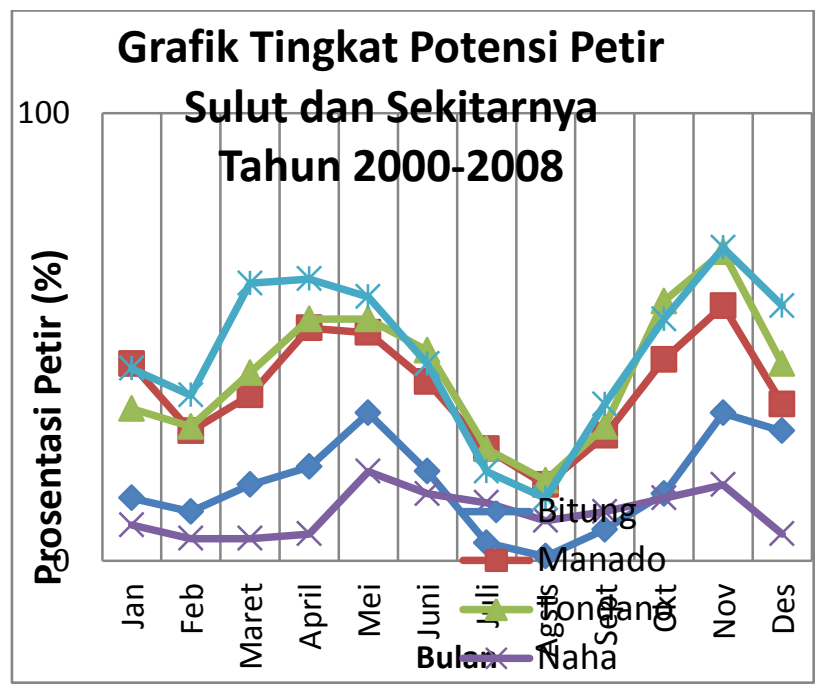

Gambar 2. Grafik Potensi Petir Pada Lima Stasiun Pengamatan 
Potensi petir terbesar kedua adalah yang tercatat di Tondano. Keadaan ini berlaku untuk Kabupaten Minahasa dan Minahasa Utara bagian selatan. Setelah Tondano, Manado menduduki posisi ketiga dengan kawasan pendeteksian meliputi seluruh Manado. Posisi keempat Bitung dengan kawasan pendeteksian mencapai Minahasa Utara bagian utara dan terakhir Naha di Kepulauan Sangihe.

Hal penting yang juga nampak dalam Gambar 2 adalah waktu kejadiaan petir dengan prosentasi terbesar. Dalam hal kejadian petir, kelima daerah pengamatan memperlihatkan pola yang sama artinya waktu kejadian petir sama untuk semua daerah. Kelima daerah menunjukkan bahwa kejadian petir maksimum terjadi pada bulan Maret-April-Mei lalu menurun pada bulan berikutnya dan minimum pada bulan Agustus untuk kemudian naik lagi dan maksimum lagi pada bulan Oktober-November lalu turun lagi hingga bulan Februari.

Pola maksimum dan minimum kejadian petir untuk kelima daerah nampak mengikuti pola musim hujan di daerah tersebut. Musim hujan dan musim panas di kelima daerah menurut data BMKG Kayuwatu Manado terlihat pada tabel 2 .

Tabel 2. Periode Musim Hujan Dan Musim Panas Sulut selama tahun 1999-2008

\begin{tabular}{|c|l|l|l|l|l|}
\hline $\begin{array}{c}\text { N } \\
\text { o }\end{array}$ & \multicolumn{1}{|c|}{ Daerah } & Musim Hujan & $\begin{array}{l}\text { Puncak Musim } \\
\text { Hujan }\end{array}$ & \multicolumn{1}{|c|}{ Musim Panas } & $\begin{array}{c}\text { Puncak } \\
\text { Musim Panas }\end{array}$ \\
\hline 1 & Bitung & November-Juni & Januari & Juli-Oktober & September \\
\hline 2 & Manado & Oktober-Juni & Januari & Juli-September & Agustus \\
\hline 3 & Tondano & Oktober-Juni & November & Juli-September & Agustus \\
\hline 4 & Naha & September-Juli & Januari & Agustus & Agustus \\
\hline 5 & $\begin{array}{l}\text { Bolaang } \\
\text { Mongondow }\end{array}$ & Oktober-Mei & Januari & Juni-September & Agustus \\
\hline
\end{tabular}

Tabel 3. Kejadian Petir Maksimum dan Musim Hujan di Daerah Pengamatan

\begin{tabular}{|l|l|l|l|}
\hline No & \multicolumn{1}{|c|}{ Daerah } & \multicolumn{1}{c|}{ Musim Hujan } & \multicolumn{1}{c|}{ Puncak Kejadian Petir } \\
\hline 1 & Bitung & November-Juni & Mei dan November \\
\hline 2 & Manado & Oktober-Juni & April dan November \\
\hline 3 & Tondano & Oktober-Juni & April dan November \\
\hline 4 & Naha & September-Juli & Mei dan November \\
\hline 5 & Bolaang Mongondow Utara & Oktober-Mei & April dan November \\
\hline
\end{tabular}

Tabel 3. menunjukkan bahwa kejadian petir paling maksimum tidak terjadi pada saat musim hujan sedang pada puncaknya tetapi justru terjadi pada awal dan akhir musim hujan atau dengan kata lain pada musim peralihan. Hal ini berhubungan dengan adanya pergerakan angin yang lebih aktif pada saat pergantian musim yang pada akhirnya angin tersebut membantu terbentuknya awan cumulonimbus sumber petir.

Data potensi petir pada Gambar 2 dan Tabel 2 menunjukkan kejadian petir rata-rata bulanan dari Januari hingga Desember. Perhitungan bulanan dilakukan disesuaikan dengan data curah hujan yang diberikan dalam hitungan rata-rata bulanan, disamping kenyataan bahwa pola pergantian musim atau cuaca bersifat periodik dan berulang salah satunya karena mengikuti pola pergerakan semu matahari.

Besarnya potensi kejadian petir secara keseluruhan dari Januari sampai Desember selama tahun 2000 sampai 2008 untuk masing-masing daerah pengamatan dapat dihitung dengan menjumlahkan potensi petir per bulan (selama sembilan tahun) kali jumlah hari per bulannya dari Januari hingga Desember, dibagi jumlah hari dalam setahun (365 hari). Hasil perhitungan diberikan dalam Tabel 4. 
Tabel 4. Prosentasi Tingkat Kejadian Petir Selama Thn 2000 s/d 2008 di Lima Stasiun Pengamatan

\begin{tabular}{|l|l|c|}
\hline No & $\begin{array}{c}\text { Daerah } \\
\text { Stasiun } \\
\text { Pengamatan }\end{array}$ & $\begin{array}{c}\text { Prosentasi Tingkat } \\
\text { Kejadian Petir Thn } \\
\text { 2000-2008 (\%) }\end{array}$ \\
\hline 1 & Bitung & 17 \\
\hline 2 & Manado & 38 \\
\hline 3 & Tondano & 42 \\
\hline 4 & Naha & 11 \\
\hline 5 & Gorontalo & 48 \\
\hline
\end{tabular}

Tabel 4. menunjukkan bahwa tingkat potensi kejadian petir untuk kelima stasiun pengamatan menurut WMO (World Meteorology Organization) berada pada kelas menengah (25 \% sampai 50\%) untuk Gorontalo, Tondano dan Manado sedang Bitung dan Naha berada pada kelas potensi rendah (kurang dari 25\%). Namun demikian harus tetap diwaspadai karena sekecil apapun potensi kejadian petir tetap mampu merusak. Selain itu, jika dilihat potensi kejadian petir bulanan, Gorontalo dan Tondano serta Manado mempunyai potensi kejadian petir pada kelas tinggi (lebih dari $50 \%$ ) pada bulan-bulan tertentu.

Data pada Tabel 4 kemudian disajikan dalam bentuk peta IKL untuk kelima stasiun pengamatan. Peta dibuat dengan menggunakan program GIS untuk mendapatkan peta kontur yang menggambarkan tingkat potensi kejadian petir. Peta tersebut disajikan seperti pada Gambar 3.

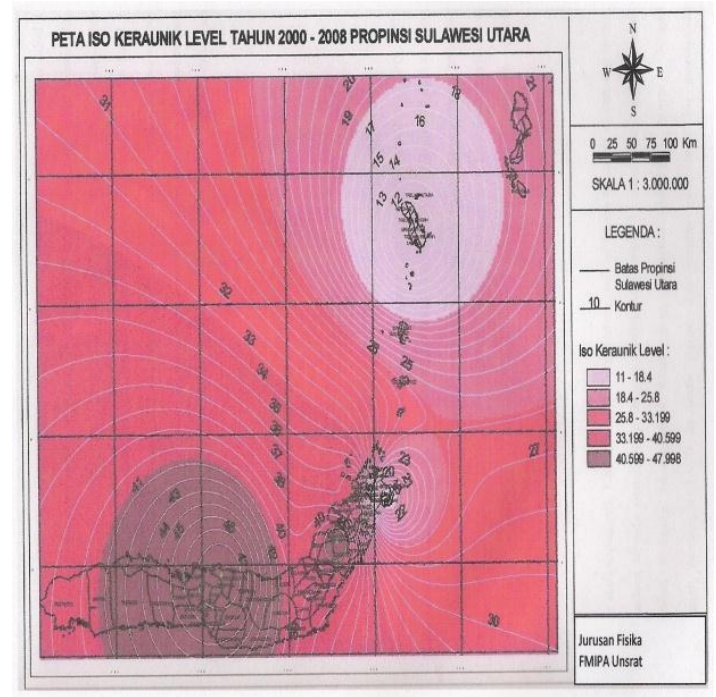

Gambar 3. Peta Iso Keraunik Level (IKL)

Sulawesi Utara Thn 2000-2008

Gambar 3. menunjukkan peta tingkat kerawanan petir pada daerah stasiun pengamatan. Stasiun pengamatan di Gorontalo yang menunjukan tingkat kejadian petir tertinggi, meliputi daerah Bolaang Mongondow Utara, sedikit Bolaang Mongondow Selatan selain tentu Gorontalo sendiri. Keadaan ini disebabkan oleh topografi Bolaang Mongondow dan Gorontalo yang bergunung-gunung dengan ketinggian mencapai $1500 \mathrm{mdpl}$ sehingga dengan penguapan yang tinggi, pergerakan angin yang cukup dan adanya gunung menyebabkan pembentukan awan cumulonimbus lebih banyak terjadi. Akhirnya tingkat kejadian petirpun menjadi lebih tinggi.

Stasiun pengamatan Tondano memberikan data kejadian petir untuk Tondano dan sekitarnya dengan angka $42 \%$. Beberapa wilayah Minahasa mempunyai topografi dengan ketinggian 500 sampai 1500 mdpl. Topografi ini ikut menunjang pembentukan awan cumulonimbus sebagai awan petir sehingga angka kejadian petir di kawasan Tondano mencapai $42 \%$ dalam sembilan tahun pengamatan. Menurut BMKG Manado, daerah dengan potensi petir seperti yang tercatat di Tondano antara lain adalah Airmadidi, Kauditan dan daerahdaerah sekitarnya.

Stasiun pengamatan Manado mencatat angka $38 \%$ kejadian petir untuk Manado dan sekitarnya. Walaupun Manado mempunyai ketinggian topografi hanya hingga 200 mdpl, kejadian petir masih cukup banyak. Hal ini karena Manado berdekatan dengan Minahasa dengan topografi yang menunjang pembentukan awan petir yaitu bergunung-gunung, sehingga wilayah Manado masih mungkin mendapat awan petir yang cukup.

Stasiun pengamatan Bitung mencatat angka $17 \%$ kejadian petir dan merupakan kelas rendah. Ini menunjukkan faktor pembentuk awan cumulonimbus sangat kurang sehingga angka kejadian petir juga rendah. Keadaan ini dapat dimengerti dari topografi Bitung yang hanya sampai 500 mdpl dengan sedikit sekali dataran tinggi. Stasiun pengamatan Naha di Kep. Sangihe mencatat angka terendah yaitu 11\%. Kep. Sangihe dan sekitarnya adalah pulau-pulau kecil dengan sebagian besar berupa dataran rendah sehingga peluang terbentuknya awan petirpun sangat rendah. 
Adapun antisipasi kejadian petir adalah dengan membuat perlindungan dari bahaya petir. Saat ini yang banyak dilakukan adalah dengan memasang penyalur arus petir atau penangkal petir di bangunan-bangunan tinggi. Penyaluran arus petir akan membuat bangunan terhindar dari kerusakan fatal akibat sambaran langsung serta mengurangi efek kerusakan pada peralatan elektronik bila ada petir yang menyambar bangunan. BMKG juga memberikan beberapa antisipasi kejadian petir antara lain:

1. Jauhi tempat yang lapang atau terbuka pada saat hujan mulai disertai kejadian petir yang signifikan

2. Usahakan tubuh serendah mungkin dengan permukaan sekitar

3. Jangan berlindung dibawah pohon yang tinggi untuk menghindari sambaran petir atau Guntur.

\section{KESIMPULAN DAN SARAN}

\section{Kesimpulan}

Sulawesi Utara selama tahun 20002008 rata-rata mengalami kejadian petir dengan prosentasi pada kelas sedang dan rendah, masing-masing untuk Bolaang Mongondow Utara 48\% (dengan stasiun pengamatan Gorontalo), Tondano 42\%, Manado 38\%, ketiganya pada kelas sedang. Selanjutnya Bitung dan Naha di Sangihe pada kelas rendah dengan prosentasi $17 \%$ dan $11 \%$. Namun kejadian petir pada bulan April, Mei dan November sebagai bulan peralihan musim, dapat mencapai kelas tinggi yaitu diatas 50\% untuk daerah Bolaang Mongondow Utara, Tondano dan Manado sedang Bitung dan Naha pada kelas sedang dan rendah.

\section{Saran}

Kejadian petir serendah apapun tingkatnya tetap mengancam kehidupan manusia. Untuk Sulawesi Utara, meskipun tingkat kerawanan petir rata-rata thn 20002008 dibawah $50 \%$ tetap harus diwaspadai dengan menyebarkan informasi tentang potensi petir ke semua lapisan masyarakat serta menggalakkan usaha-usaha untuk meminimalisasi dampak kerugian sambaran petir.

\section{DAFTAR PUSTAKA}

Griffiths, D.J. 1995. Introduction to Electrodynamics, $2^{\text {nd }}$ edition. Prentice Hall of India Private Limited.

Lee R. Kump, Kasting, J.F., Crane, R.G. 2010. The Earth System, $3^{\text {nd }}$, Prentice Hall.

Munawar, W. O. 2010. Kajian Curah Hujan berdasarkan Data Kelembaban dan Penguapan. Skripsi Sarjana FMIPA Unsrat.

Pinto Jr, O., Pinto, I.R.C.A., Naccarato, K.P. 2007. Maximum cloud-to-ground lightning flash densities observed by lightning location systems in the tropical region: A review. Atmospheric Research, Volume 84, Issue 3, Pages 189-200.

Price, C. 2009. Will a drier climate result in more lightning?. Atmospheric Research Volume 91, Issues 2-4, Pages 479-484 .

Sulistyanto, H. 2002. Efek Interferensi Medan Elektromagnetik terhadap Lingkungan. Jurnal Teknik Elektro Emitor, Vol. 2. No. 2.

Salmawati. 2010. Studi Pengaruh Indeks Osilasi Selatan sebagai Indikator ElNino terhadap curah hujan di Sulawesi Utara. Skripsi Sarjana FMIPA Unsrat.

Tjasyono, B.HK. 2008. Meteorologi Terapan. ITB Bandung.

Tjasyono, B.HK. 2005. Sains Atmosfir. ITB Bandung.

Tjasyono, B.HK. 2001. Mikrofisika Awan dan Hujan. ITB Bandung.

Uman, M.A. 2001. The Lightening Discharge. General Publishing Company, Ltd, Ontario.

Wahid, R.M. 2009. Studi Tingkat Potensi Petir di Sulut. Skripsi Sarjana FMIPA Unsrat.

Zoro, R. 2009. Induksi Dan Konduksi Gelombang Elektromagnetik Akibat Sambaran Petir Pada Jaringan Tegangan Rendah. Makara, Teknologi, Vol. 13, NO. 1, 25-32. 